Article

\title{
Incumbent Decisions about Succession Transitions in Family Firms: A Conceptual Model
}

\author{
Britta Boyd ${ }^{1, *}$, Isabel C. Botero ${ }^{2}$ and Tomasz A. Fediuk ${ }^{3}$ \\ 1 Department for Border Region Studies, University of Southern Denmark, Alsion 2, \\ 6400 Sønderborg, Denmark \\ 2 Department of Management, Gatton College of Business and Economics, University of Kentucky, \\ Lexington, KY 40506-0034, USA; E-Mail: Isabel.botero@uky.edu \\ 3 Fediuk Botero LLC, Lexington, KY 40515, USA; E-Mail: tafediuk@fedtero.com \\ * Author to whom correspondence should be addressed; E-Mail: bri@sam.sdu.dk; \\ Tel.: +45-(0)-6550-1756; Fax: +45-(0)-6550-1779.
}

External Editor: Esra Memili

Received: 30 April 2014; in revised form: 29 July 2014 / Accepted: 24 October 2014 / Published: 3 November 2014

\begin{abstract}
In the family business literature, succession research has focused on the family member as they enter the leadership role or on the different issues that affect the succession process. Although researchers have acknowledged that succession in family businesses is "punctuated" by decision making events, less attention has been given to understanding how incumbents make decisions about ownership and management transitions. In an effort to continue to understand the succession process it is important to understand how incumbents make decisions about the type of transitions they intend to engage in (i.e., intra-family succession, out of family succession, or no succession). Building on the theory of planned behavior and the socioemotional wealth framework (SEW), this manuscript presents a conceptual framework to understand the factors that influence succession transitions and the role that contextual factors can play in this decision-making process. We present theory driven propositions and discuss the implications for understanding and evaluation of the succession process.
\end{abstract}

Keywords: decision-making; ownership transition; management transition; succession intent; succession in family firms; theory of reasoned action 


\section{Introduction}

Succession has been one of the main areas of interest for family business scholars and practitioners. The reason for this is that only a small percentage of family firms are able to survive the transition to the next generation [1], and poor succession planning and management is often attributed as the main reason for this poor survival rate [2]. Although there are several integrative frameworks that explain the succession process in family firms [3-6] and there is research highlighting the factors that prevent intra-family succession [7], an aspect that is not well understood is how incumbents ${ }^{1}$ make decisions about the type of succession they intend to engage in (i.e., intra-family succession, out of family succession, or no succession). This decision-making process is important because the way that owners plan, manage and execute the succession of a firm is intrinsically linked to their decision about the type of transition they intend to engage in, can have an effect on how the succession process is evaluated, and the financial viability of the family and the business.

In the context of family firms, succession refers to the transfer of management and/or ownership from one family member to another [3,6]. Although research on succession has tried to understand the range of factors that are related to successful succession, there is not much understanding of determining what succession strategy founder/owners decide to engage in and why [8]. This gap in our understanding has affected the evaluation of what constitutes a successful succession and has promoted the assumption that in family firms exit strategies that have a non-family focus represent a failure for the family [9]. This assumption is inconsistent with empirical research that has found that the performance of family CEOs is affected by organizational size and concentration of ownership among family members such that firms with family CEOs perform better when the firm is smaller and the ownership is concentrated among family members [10]. Because of this, family business scholars have started to highlight the decision-making components of the succession process as an important source for understanding other exit alternatives. For example, De Massis and colleagues [7] suggest that the succession process is a "chain of causation" that begins with the decision of the incumbent or dominant coalition regarding the type of transition they hope to engage in based on an evaluation of the availability of successors to take over the business. Similarly, Royer and colleagues [5] suggest that before family firms begin the succession process they often analyze the costs and benefits of keeping the business in the family in comparison to finding other forms of succession (e.g., selling the business or having non-family management). These authors argue that in instances where intra-family succession becomes costly for the family business, owners will make different decisions of how to approach the succession process.

The work on transgenerational intent [11,12] (i.e., the desire of organizational leaders to hand over control of the firm to their children) and transgenerational control intentions [13] (i.e., intention to transfer the control of the business to the next generation) also suggests that the succession process begins with a decision-making event in which owners consider the benefits and costs of transferring management and control of the business to family and non-family successors. Finally, DeTienne and Chirico [14] recently present a conceptual model to explain how socioemotional wealth (SEW; i.e., the

1 Incumbents in our paper represents an individual who currently holds the management leadership position in a family firm, has majority of ownership in a business or represents those who have majority ownership in the family firm. 
nonfinancial aspects that motivate family business owners) affects the founder's decision to exit the family business. They argue that family firms with higher levels of SEW are more likely to select stewardship exits (i.e., exit strategies that focus on keeping the family involved in the business either through ownership or through management).

When taken together, these studies suggest that before a succession can be planned/managed, the incumbent needs to make a decision regarding the type of transition to follow. Up to date, we have very little understanding of what factors play a role in making decisions about transitions, and how these factors affect the choices that incumbent make regarding transitions. This is problematic for two reasons. First, if researchers do not understand the complete succession process, including how incumbents make decisions about what type of succession they will follow, there might be key issues that are not being considered when studying the effectiveness of succession. Second, the incomplete understanding of the succession process can also limit the help that academic research can provide to practitioners (i.e., consultants and family business owners). Thus, in an attempt to address the gap highlighted above, this paper presents a conceptual model that addresses two important research questions: (1) What factors play a role in the incumbent's decision to engage in a particular type of transition? And, (2) how do these factors influence the incumbent's decision of what transition to engage in? (See Figure 1).

Building on the theory of planned behavior [15], and the work on socioemotional wealth [16] we identify the contextual factors (i.e., family, business, industry, and culture) that play a role in the incumbent's decision of what type of succession to engage in (i.e., intra-family succession, non-family succession, or no succession). We also explore how contextual factors influence this decision making process based on the importance that the incumbent places on socioemotional wealth factors (i.e., concern for the family and concern for the business). We believe that the conceptual model presented in this paper can provide some insights for academics and practitioners. For academics, our model can serve to understand what are factors that are understudied when exploring the different types of succession and why they occur. For practitioners, our model can provide some guidelines of aspects that need to be considered when helping family business owners make decisions about transitions, and how to plan and manage these transitions. In the following sections we summarize literature in the areas of family business, entrepreneurship and social psychology to present our theoretical model of how incumbents make decisions about succession transitions. We finish our paper by discussing the implications of our model and some ideas for future research. 
Figure 1. Incumbent decision making transitions model.
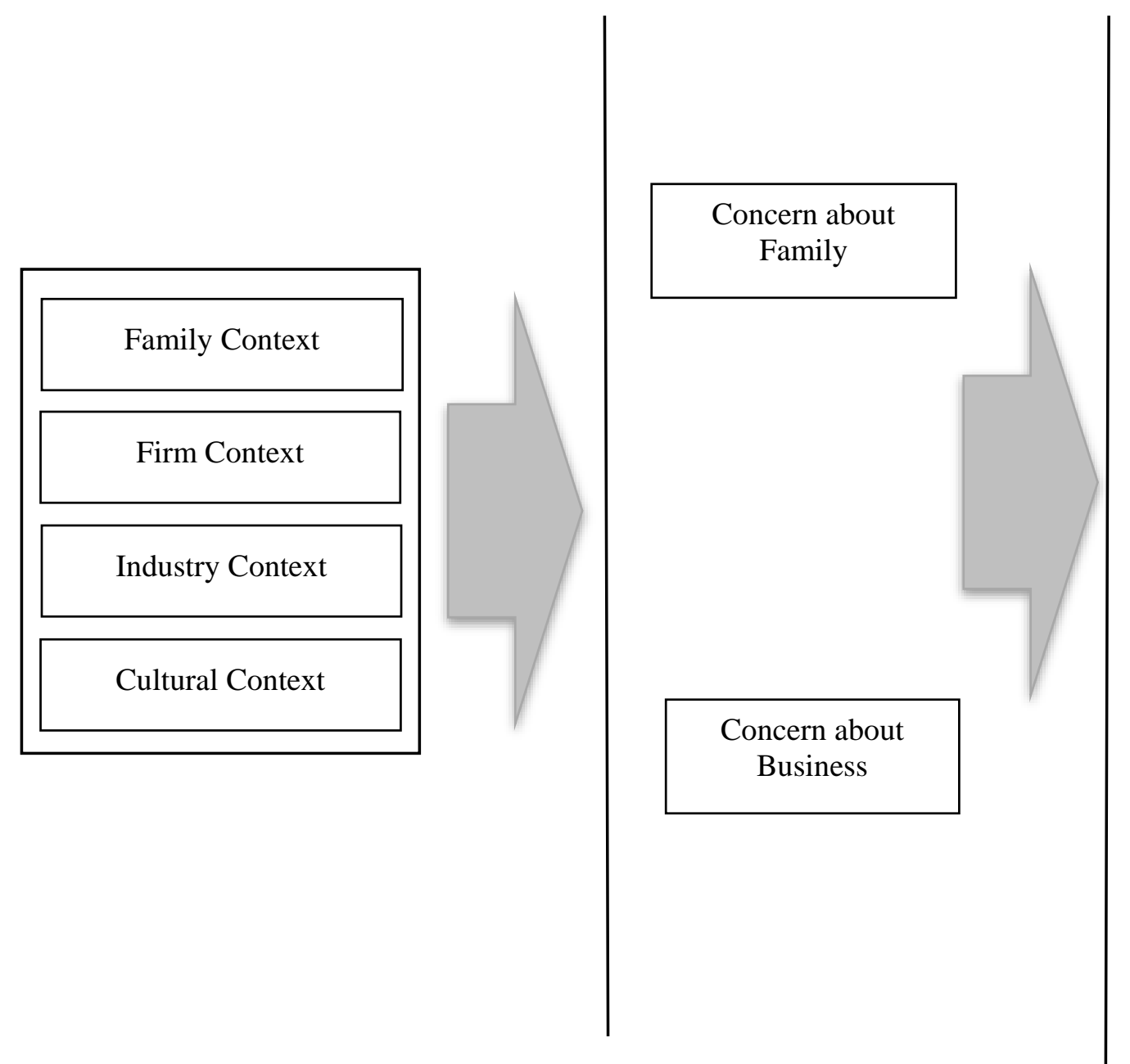

Attitudes towards the Type

\section{of Succession:}

- What does the incumbent think

about this type of transition?

- Are these thoughts good or bad?

\section{Subjective Norms:}

- Perceptions of important others

about the type of transition.

- Intention of the incumbent to

comply with important others.

\section{Perceived Behavioral Control:}

- Incumbent's judgment of the availability of resources and opportunities required to engage in a specific transition.

- Incumbent's perception that having the resources will facilitate the transition. 


\section{Literature Review: Succession in Family Firms}

Family firms are organizations in which family involvement characterizes the management, control, and ownership of the business $[17,18]$. These types of firms represent a significant proportion of the world's organizations and a large percentage of GDP for multiple countries [19]. Because of this, in the last three decades there has been growing body of research dedicated to exploring the uniqueness of family firms, the challenges that they face, and the factors that affect their survival. One of the main concerns highlighted by previous work is the challenges family firms face when transitioning management and ownership of the firm from one generation to the next. Findings suggest that family firms are not very successful in this transition process because only a small percentage is able to survive [1]. This concern has led to a focus on intra-family succession as one of the major areas of interest for family business scholars and practitioners $[4,20]$.

Although family business succession has been defined multiple ways, it includes the transfer of leadership and ownership from a senior to a junior generation [3,21]. Leadership succession encompasses the transition and transfer of the responsibility for the ongoing management of the family firm to a junior generation of the family or an outside member; while ownership succession includes the distribution of "shares or other measures of ownership" of the firm from senior to junior generations [8,22]. A great deal of family business research is dedicated to understanding the succession process, the problems in this process, and how these problems can be prevented or resolved [3,6,7,21]. This research has been summarized in several models that try to explain how succession occurs. Each of these model focuses on different aspects or actors of the succession process. For example, Longenecker and Schoen [23] and Churchill and Hatten [24] present succession models that focus on the on the successor as they move through stages of transitions. On the other hand, the work of Sharma and colleagues [6] focus on the interpersonal (e.g., acceptance of new roles, fit between successors career interests and the business, and trust in the successor) and decision-making and planning factors (e.g., agreement to continue in the business, the extent of planning for succession) that influence initial satisfaction with the succession process. In another work, Le Breton-Miller and colleagues [3] proposed an integrative model that explains what it takes for succession to succeed. This model indicates that succession is the sequence of four main stages: (1) establishing ground rules, (2) nurturing and developing a pool of potential successors, (3) selection, and (4) handoff to the chosen successor. They argue that there are four contexts that affect the succession process: industry, business, family and social. Finally, the model of De Massis and colleagues [6] suggests that the succession process is a “chain of causation” that begins with the dominant coalition's desire to engage in the succession process and the availability of a potential successor. These authors argue that the succession process begins with a decision-making event and ends when the incumbent relinquishes management and ownership control to the next generation (For a detailed review see the chapter by Long and Chrisman [4]).

There are several commonalities shared by these succession models. First, they all view succession as a long-term process and not a single event. This implies that can include several stages or steps. Second, these models imply that for succession to occur there needs to be both a desire from the 
dominant coalition ${ }^{2}$ to pass the business on to others and the availability of a potential successor to take over the business. Third, these models suggest that the succession process is accentuated by several decision-making events [8] and culminates with the transition of leadership/management and ownership from one generation to another. And, fourth, there is the assumption that the success of the succession process is based on keeping the management of the business in the family.

Although decision-making events play an important role in the succession process, there is a gap in our understanding of how the incumbent and the dominant coalition in a family firm make decisions about transitions and the different factors that play a role in this decision-making process $[7,8,14]$. With this in mind, the focus of this paper was to develop a conceptual model to understand the factors that play a role in the incumbent's initial decision regarding the type of succession transition they would want to follow and how these factors affect decisions. We believe that this initial decision is important because it affects how owners approach other decisions in the succession process. In the following section we describe how we view the decision-making process about ownership and management transitions.

\section{Making Decisions about Management Transitions}

Before the succession process can be initiated, incumbents need to make decisions about what type of succession to engage in. Researchers that explore succession transitions in the family business context have explored it under the label of "exit strategy" of the founder [14]. DeTienne [26] defines exit strategy as the entrepreneur's decision to leave the firm that they decided to create. Given that in family firms owners might choose to leave the management of the firm while keeping ownership in the firm, we have decided to use the term succession transition to explain the decisions that incumbents make regarding who to transfer the leadership/management control in the family firm. Similar to other authors [26,27], we view succession transitions and exit planning as an important component of the entrepreneurial process, and focus on what DeTienne and Chirico [14] label as individual exit strategies or succession transitions at the individual level.

This paper considers three types of succession transitions: intra-family succession, non-family succession and no succession. Intra-family succession transition refers to the transfer of management to a family member that takes control of the family business when the incumbent decides to step down. Non-family succession transition represents the transfer of management to an individual who is not part of the family. In these situations, the family might transfer the leadership/management of the firm, but may not transfer the ownership to non-family managers. Thus, the non-family manager may be in this role until the family prepares someone to take over or may stay in this position for a long time. Finally, no-succession represents situations where the owner of the business decides to keep control of the firm at all costs, terminate the business or decides to sell the firm outside of the family.

Research in family business places great importance on the owner's intentions to keep the control of the business in the family is one of the most important concerns for family owners $[17,28]$. This intention to keep control in the family is associated to the family's commitment to the business [29],

2 Similar to De Massis and colleagues (2008) [6] and Gersick and colleagues (1997) [25] we define the dominant coalition as a single individual (e.g., founder of a family business) or many individuals who have ownership and management control over the business. 
and serves as an indicator of the importance attached to family non-financial goals [30]. Thus, most of the research on succession in family firms has focused on intra-family succession as the primary transition strategy used by incumbents in family firms. An underlying assumption for focusing on intra-family succession is the belief that this type of succession is the one that will bring success to firm and will help preserve the family legacy throughout generations [9,14]. Empirical research has provided mixed results when evaluating whether family firms that are family managed outperform other types of organizations [10]. In their empirical study exploring the difference in performance between family firms managed by family CEOs and other CEOs, Miller and Colleagues [10] found that family firms that were managed by family CEOs were likely to outperform other organization when these firms where smaller and the ownership was highly concentrated among family members. In other conditions there were no differences in performance.

Given this empirical evidence, we believe that the focus on keeping the business in the family has led us to have less understanding regarding the consideration of other transition options and how family business owners make decisions about management transitions in general. This gap is important to address because it can expand the understanding of scholars and practitioners at least three different ways. First, it can provide a complete picture of the succession process that includes decision to engage in a type of succession transition, planning for the succession, executing the succession plan, and giving control to the next generation. Second, it can help scholars and practitioners articulate the meaning of the success of the succession process as one that is tied to the goals of the incumbent and the dominant coalition. And, third, it can help us understand how decision-making about transitions can influence other processes in the family and the business and how contextual factors can also influence decisions about transitions.

\section{The Theory of Planned Behavior}

The theory of planned behavior (TPB) provides a good conceptual framework to understand the factors that influence decisions about ownership and management transitions. The central premise of this theory is that decisions about behaviors are a logical sequence of cognitions [31]. Thus, individuals rationally make decisions about their actions using the information they have access to. This theoretical framework suggests that individual motivations to engage in a behavior (i.e., behavioral intention) are the strongest predictors of behavior [15,32]. According to TPB behaviors are the result of a decision making process by which a person or group of people evaluate their intentions towards engaging in a behavior, the attitudes they have towards the behavior, how significant others evaluate that behavior, and their personal evaluations of how easy or difficult it is to perform a behavior [15,32]. In this theory, attitudes represent the affective responses that individuals hold towards a behavior [33] and are the summation of the beliefs held about the behavior and the evaluation of those beliefs [31]. Research suggests that before committing to a behavior, individuals first evaluate and prioritize their beliefs towards the behavior, and the stronger the belief towards the behavior the more likely the individual will be to develop intentions to perform it [33].

Although personal beliefs play an important role in determining intentions, individuals also rely on the beliefs of others. In TPB, subjective norms assess how valued social networks feel about the individual engaging in a behavior and the importance of these networks in influencing the 
individual [33]. Subjective norms can reflect the beliefs from valued social networks but can also represent general societal values and norms, as well as intrapersonal beliefs [34]. In this context social networks include family members, close friends, co-workers, and can also include members of a club, group, or ethnicity that are important to the individual. This theoretical approach argues that individuals make sense of others' beliefs by first assessing the expectations of others and then examining their personal motivations to comply with these expectations. Thus, TPB indicates that individuals will intend to engage in a behavior when their valued social networks have positive evaluations towards that behavior and the individual wants to comply with these important social networks. Finally, perceived behavioral control represents the individual's perception of how easy or difficult it will be to perform a behavior [35]. The assessment of the individual's control is based on two factors: control beliefs (i.e., beliefs regarding the presence or absence of the resources/opportunities necessary to perform a behavior) and perceived power (i.e., evaluation of whether having the knowledge about the resources and opportunities will help perform the behavior).

In the context of family firms, TPB has been used to explore the effects of paternalistic leadership on perceptions of successors [36], the determinants of career choice intentions for individuals with a family business background [37,38], the effects of prior family business exposure on entrepreneurial intent [39], financial decision-making in family firms [40], family member involvement in the firm [41], and the predictors for engaging in environmental management practices [42]. Most of these studies used TPB as a framework to understand how people make decisions about engaging in a behavior. Thus, we wanted to apply this decision-making framework to the context of succession transitions in family firms. When applied to making decisions about transitions in family firms, TPB would indicate that the type of succession that an incumbent intends to engage in is dependent on the attitudes that the incumbent has about a type of succession, what important others think about this type of succession, and the individual perception of how easy or difficult it would be to engage in that type of succession.

\section{Socioemotional Wealth (SEW)}

Family firms are unique in that they combine two important subsystems as part of the firm: the family and the business [43]. Because of this unique composition, an owner's decision of what type of succession to engage in will be greatly influenced by their considerations of the family and the business. Family business researchers indicate that family firms are unique because they can derive value from the economic success of the business and from non-economic affect related issues such as the perpetuation of the family legacy, the visibility of the firm or the perpetuation of family values through the business [44]. This is known as the socioemotional wealth framework (SEW). SEW represents the non-economic and emotional value that owners associate with a family firm and helps achieve the family affective (e.g., identity, influence, and perpetuation of the family dynasty [45]). Thus, SEW plays an important role when making strategic decisions about a family firm.

Family firms vary in the extent to which they focus on financial and non-financial goals [46]. Thus, we argue that concern about the family and the business are important when making decisions about succession transitions. Concern about the family represents the degree of importance that the incumbent gives to the family. This is consistent with the ideas of high SEW. That is, incumbents that are high on concern for the family believe that family dynamics, family resources, the family legacy, 
the survivability of the family, and/or rivalries/conflict between family members are important factors to consider when making decisions about transitions. On the other hand, concern about the business describes the degree of importance that the incumbent places on the business. In this process the owners determine how a transition decision will impact the survivability of the business, the attitudes of non-family workforce, profitability, ability to manage the business, competition, innovation, and perceptions of legitimacy of the organization. Thus, we believe that the SEW is a useful framework to understand the factors that play a role in making decisions about transitions and why these factors impact this decision-making process.

\section{Conceptual Model to Understand Transition Decisions}

Although considerations about the family and the business play a central role in the decision-making of family business owners, there are contextual factors that can affect how the owner evaluates their concerns about the family and the business. Previous research provides some ideas of the different contexts that need to be assessed to be able to make a decision about the succession process. Le Breton-Miller and colleagues [3] suggest that to fully understand the succession process in family firms there are four contexts that need to be considered: the family, the business, the industry, and the cultural context. We believe that these contexts also play an important role in scanning the environment to be able to weigh the considerations about the family and the business when making decisions about what type of succession to follow in the family firm.

As viewed in this paper, the type of succession transition that a family firm decides to engage in is the result of a decision-making process that an owner/incumbent goes through to determine the future of how their business will be governed and/or managed (i.e., will business leadership/management of the firm be transferred to others inside the family? to non-family managers? Or will the business be sold out of the family?). We argue that the intention towards a particular type of succession transition is the result of an evaluation process by the owner of a firm that has several stages (See Figure 1). In the first stage, the family business owner evaluates four components of their environment (i.e., the family, the business, the industry, and the social/cultural contexts) to determine the effects that the particular type of succession could have on the family and on the business. In the second stage, the owner uses their evaluation of the contextual factors to determine what considerations they have about the family and the business. Once they have collected enough information, the family business owner will weigh their concerns for the family and their concerns for the business to evaluate their attitudes towards the three different types of succession (i.e., intra-family succession, non-family succession, or no succession), the beliefs of important others regarding the different types of succession, and they perceptions about how easy or difficult it will be for them to achieve each type of succession transition. The combination of these opinions will determine which type of transition the owners intend to engage in.

There are a few boundary conditions that are important to consider when interpreting our model. First, this model is based on the assumption that family business owners go through a decision process that is primarily rational. That is, even though there are affective considerations when making decisions about transitions, an incumbent is capable of evaluating different features of the family, the business, and the context to better understand the strengths and weaknesses of their firm and their 
family regarding each type of transition. Second, we also assume that business owners are able to weigh the positives and negatives of the decision they make. That is, we assume an incumbent is able to predict the consequences that a decision can have for a family and a business. Third, we believe that decisions about succession transitions differ from the decision of when to start the succession process (i.e., succession planning and management) and who to choose as a successor. Thus, the reader should be cognizant that this paper only focuses on the decision of what type of succession to engage in and not when the succession should occur or who would be the best successor for a firm. Fourth, this model is interested in leadership/management transitions in family firms. Thus, our ideas may not apply when evaluating ownership transitions in the family firm. Finally, we focus on the incumbent or the family business owner, and assume that their decision to transition out of the leadership of the family firm is voluntary and intentional. Thus, this model would not apply to transitions that result from death or hostile takeover. With this in mind, the following sections explain the different factors that are evaluated and how they affect decisions about succession transitions.

\section{Contextual Factors Influencing Evaluations of Succession Transitions}

Previous research on family firm succession provides some ideas of the different contexts that need to be assessed to evaluate the transitions available during a succession. Le Breton-Miller and colleagues [3] suggest that to fully understand the succession process in family firms there are four contexts that need to be considered: family, business, industry, and social/cultural (see Table 1). We believe that these contexts play an important role when the incumbent is scanning the environment to make their decisions about transitions. We argue that incumbents need to understand and evaluate these four contexts to determine the concerns they have for the family and the business if they decide to engage in the succession process.

The evaluation and understanding of the family context includes gaining knowledge in at least three areas: family dynamics, availability and willingness of a successor, and family influence and commitment to the business. Family dynamics represents the evaluation of factors such as family harmony (i.e., how well do family members get along), level of collaboration of family members, quality of the relationship between family members, the level of trust between family members, and the quality communication in the family. Previous research exploring the succession process has found that family dynamics play a critical role in the success of a succession process [3]. In particular, family environments that are characterized by collaboration, accommodation, harmony and positive sibling relationships are more likely to be successful during the succession process $[6,47,48]$. The availability and willingness of a successor is the second aspect of the family context that needs to be evaluated. Before an owner can decide what type of succession they want to engage in, they need to know whether they have qualified individuals that can take over the business, what is the motivation of the possible successors, what is their leadership preparation, what is the knowledge that they have about the business, and what are the abilities that they could bring into the business. Previous research has suggested that all of these factors are important in determining the success of the succession process [3,10]. Thus, it is not only the availability of a successor, but the willingness and the preparation that this successor has that can impact the concerns of an owner for the succession process and its effects on the family and the business. 
The third and final component of the family context is the level of influence and commitment that the family has with the business. Lansberg and Astrachan [49] found that the family's commitment to the business and the relationship quality with the successor have a positive effect on succession planning and training. Some aspects that need to be considered when looking at commitment are the financial support that the family provides to the business, the availability of a family council and a family protocol/constitution, and the number of family members that are owners or work for the family firm [3]. All of these factors should influence the family-business interaction to help the owner assess the viability of a successful succession process. We believe that the evaluation of the family context will play an important role in the owner's assessment of considerations about the family and the business that they need to evaluate. This information is important because it helps the owner evaluate the readiness of the family with regard to the succession process and how this can impact the business. The family information helps the owner assess the strengths and weaknesses they currently have if they were to engage in the succession process.

The business/firm context is the second aspect that will influence the considerations that owner's have about the family and the business when thinking about the succession process. When evaluating the business context, owners consider information in several areas. First, the owners evaluate the general economic/financial state of the business, which includes information about the current business strategy, how this strategy is being applied, the current financial state of the business, the viability of the business in the future, and the potential for future economic and financial success. By considering this information the family business owner is able to ascertain what the current and future economic viability of the business is. Economic viability will be important because it will determine what type of succession the owners are willing and able to engage in [40,50]. The second type of business information to consider would be organizational size. Organizational size can be represented as the number of employees a firm has or by the sales that it produces every year. The work of Miller and colleagues [10] suggests that firm size is an important indicator of administrative complexity and places cognitive limitation on those who are responsible for managing the firm. They argue that in larger organizations there are more complex control and monitoring systems that require more formalized managerial skills and the mastery of management practices that are required by the future manager of the firm. Thus, understanding the complexity brought about by organizational size is important when making decisions about transitions.

The third type of information in the business context is concentration and dispersion of ownership between family members. Given that family firms are likely to provide the economic means to the family, a family business manager is likely to be vigilant and caring of the company, specially when it is smaller and ownership is concentrated between a few family members [10]. When ownership is more diffused between family members (i.e., there are generations of family members involved) there is a higher likelihood of fractions in the business ownership that cause family CEOs to be a liability [51]. Thus, the incumbent needs to understand these issues to figure out what transition strategy will work best with the firm and the business. The final component of the business context is the culture of the organization. This includes understanding the values of the business, the commitment of family and non-family employees to the success of the business, the level of diversity present in the business, the general climate of the organization, and the level of adaptability that the people in the business have to deal with changes in the industry and changes in the business. We believe that these three areas of 
information about the business will help the owner create a picture about the strengths and weaknesses in the family firm to determine what type of succession transition is best for the firm, what needs to be done for succession to occur, and how the choice to engage in a succession process can affect the family and the business.

The industry context represents the evaluation and understanding of information about an industry that is critical in planning how to successfully lead a firm. This context is important because it determines the qualities required for the successor of a firm and can help the incumbent determine whether the family has a potential successor or can develop a potential successor. Although there has not been a lot of research articulating which characteristics of an industry may influence the selection of a successor to a firm, the work from Royer and colleagues [5] suggests that the type of knowledge required in an industry can affect whether a family member or an outsider is a better fit as a successor in a firm. These authors suggest that family insiders are better as successors in conditions where there is higher relevance for experiential family business specific knowledge and when the family insider is better qualified than outsider regarding general and technical industry specific knowledge. Other information about the industry that may be important for an owner to determine what type of succession to engage in includes where the industry is heading, how is the industry changing, how is the industry growing, and what are the challenges of the industry is facing? All of this information can help owners determine what type of succession process a firm can handle and how this decision will affect both the family and business subsystems.

Table 1. Research on the different contextual factors that influence succession decisions.

\begin{tabular}{|c|c|c|}
\hline Context & Variables & $\begin{array}{c}\text { Sources } \\
\end{array}$ \\
\hline Family & $\begin{array}{l}\text { Family dynamics } \\
\text { Availability and willingness of a successor } \\
\text { Family influence } \\
\text { Commitment to the business }\end{array}$ & $\begin{array}{l}\text { Le Breton-Miller et al. [3]; } \\
\text { Morris et al. [47]; } \\
\text { Potts et al. [48]; } \\
\text { Sharma et al. [6]; } \\
\text { Habbershon \& Pistrui [52]; } \\
\text { Lansberg and Astrachan [49] }\end{array}$ \\
\hline Firm & $\begin{array}{l}\text { General economic state } \\
\text { Financial considerations } \\
\text { Governance and ownership structure } \\
\text { Culture of the organization }\end{array}$ & $\begin{array}{l}\text { Le Breton-Miller et al. [3]; } \\
\text { Potts et al. [47]; } \\
\text { Sharma et al. [6]; } \\
\text { Koropp et al. [40]; } \\
\text { Molly et al. [53] }\end{array}$ \\
\hline Industry & $\begin{array}{l}\text { Type of industry } \\
\text { Industry growth } \\
\text { Challenges } \\
\text { Taxation }\end{array}$ & $\begin{array}{l}\text { Royer et al. [5]; } \\
\text { Le Breton-Miller et al. [6]; } \\
\text { Greens Analyseinstitut [54] }\end{array}$ \\
\hline Culture & $\begin{array}{l}\text { Cultural influences } \\
\text { Social norms, ethics and religion } \\
\text { Laws }\end{array}$ & $\begin{array}{l}\text { Lee et al. [55]; } \\
\text { Goto [56]; } \\
\text { Royer et al. [6]; } \\
\text { Le Breton-Miller et al. [3]; } \\
\text { Birley [57]; } \\
\text { Birley, Ng and Godfrey [58]; } \\
\text { Yan and Sorensen [59] }\end{array}$ \\
\hline
\end{tabular}


The final context that we consider in this paper is the cultural context. The cultural context involves the evaluation and understanding of information that pertains to culture, social norms, ethics, and laws that can affect the succession process. There is not much research in this area, but the limited international projects that have explored family firms in different cultures suggest that culture can affect the succession process. For example, Royer and colleagues [5] argue that Japanese family firms may have a longer life span because they have a higher concern for long-term orientation and they have a preference for internal successor [56]. Thus, the Japanese culture promotes the idea of transforming individuals into family insiders to enable an internal succession to occur [55]. Yan and Sorenson [59] investigated the effect Confucian values on family business succession and stressed the importance of examining values across cultures to identify underlying intent or principles in a certain culture. Similarly, the work of Birley and colleagues [57,58] indicates that culture affects an owner's attitude towards involving the family in the business. Given this, we believe that the cultural context also plays an important role in deciding what type of succession to engage in. In particular, we think family business owners assess information about the context (i.e., laws, cultural expectations and norms) to determine the strengths and weaknesses that they have for a type of succession to occur.

When making decisions about transitions, the incumbent's familiarity with these four contextual areas provides them with a general understanding of the environment in which a transition will take place. Thus, knowledge about these contextual factors will help incumbent's assess the cost and benefits for the family and for the business of any decision. Building on this line of thought, we suggest the following proposition:

P1: Before making decision about succession transitions, incumbents should evaluate the family, firm, industry and cultural contexts in which the firm operates to be able to assess what type of succession transition they are capable of engaging in.

\section{Importance Given to the Family and the Business}

One of the characteristics that differentiate family firms from other types of organizations is the importance given to non-economic aspects of the business. Researchers suggest that the value given to non-economic aspects of the firm affects the decisions and behaviors that family managers and owners follow in their business [60]. This is not to say that family business owners ignore the importance of business or financial aspects of the firm [46]. Thus, we believe that when evaluating decisions about transitions it is important to separate two areas of the family firm: the family, and the business. In our model we describe concern about the family as the importance that the incumbent gives to family aspects in the business. This includes the future of the family, the preservation of family harmony, and the preservation of the family legacy inside the family and inside the business. We believe that the concern that an incumbent has about the family will play a role in the attitudes they develop towards a type of transition, how they interpret the subjective norms about a transition, and their evaluation of how difficult or easy it will be for them engage in a specific type of transition. For example, when an incumbent has high concern for the family and the preservation of the family legacy, they will have a tendency to develop stronger positive attitudes towards family-transitions in comparison to non-family or no transition. On the other hand, when an incumbent has low concern for the family, they will be more likely to have positive attitudes towards non-family transitions. A similar issue may play out 
when evaluating subjective norms. That is, when an incumbent has high concern for family, they will be likely to consider and comply with the evaluations of family members when making decisions about transitions; while when the have low concern for family the incumbent may value and comply with the opinions of friends or employees as important others. Thus, building on this idea we propose the following:

P2: The incumbent's concern about the family will affect their attitudes, subjective norms, and perceived behavioral control when evaluating the type of succession transition to engage in.

Concern about the business describes the importance that an incumbent gives to the company as a whole. This can include the importance given to the preservation of the business, the financial performance of the business, responsibility towards non-family employees in the business, and the potential future of the business. The importance given to the business will also affect the attitudes that incumbents have towards transitions, the interpretation of subjective norms and the perceived personal control. For example, incumbents who believe in the importance of the business will pay close attention to the effects that a transition may have on a business. Thus, incumbents will have positive attitudes towards transitions that will help the business survive and achieve future success. The importance given to the business will also affect whose opinions the incumbent values. In the case when there is a high concern for the business, the incumbent will be likely to value and comply with the opinions of important employees and important individuals in the business. Building on this rationale with advance the following proposition:

P3: The incumbent's concern about the family will affect their attitudes, subjective norms, and perceived behavioral control when evaluating the type of succession transition to engage in.

Table 2 shows how the incumbent can combine the evaluation of these two important aspects of the family business when making decisions about transitions. In this case, incumbents would be likely to engage in intra-family succession when there is a high concern for family and high concern for business. Intra-family succession could also be an option when the owner perceives that there are positive considerations for the family from taking over the business and there might be some costs for the business. Under these conditions the incumbent believes that the benefits for the family can outweigh the costs for the business. Non-family succession is likely to be an option under two conditions. First, when an owner believes that choosing a family successor might bring a serious disruption into the family (i.e., negative family consideration) and they believe that the business is in a positive state. Under these conditions costs for the family may persuade the business owner to think about involving an outsider in the management of the firm. The second situation would be when the owner does not see that the future successor is ready to take over the business (e.g., she/he is too young, or does not have enough education/knowledge about the business at this point). Under these circumstances owners will be likely to consider non-family succession to have enough time to prepare the next family successor. Finally, a family business owner will consider no succession or selling the business when the costs for the family and for the business are very steep. In these situations they 
might believe that selling the business or not engaging in succession may be the best choice for the business and the firm to survive.

Table 2. Considerations towards family and business and their effects on decisions about succession.

\begin{tabular}{|c|c|c|c|}
\hline & \multicolumn{2}{|c|}{ Concern about Family } \\
\hline & & Low & High \\
\hline \multirow{2}{*}{$\begin{array}{l}\text { Concern } \\
\text { about the } \\
\text { business }\end{array}$} & High & $\begin{array}{l}\text { Owners in this quadrant believe that the } \\
\text { business has a future and that succession } \\
\text { should occur. They also believe that for } \\
\text { the family it would be costly to engage in } \\
\text { a succession process given the current } \\
\text { personnel they have. Because of this, } \\
\text { they will be likely to decide towards a } \\
\text { non-family succession. }\end{array}$ & $\begin{array}{l}\text { Owners in this quadrant view the benefits } \\
\text { for the family and for the business of } \\
\text { engaging in succession. Because of this, } \\
\text { they will be the most likely to engage in } \\
\text { intra-family succession. }\end{array}$ \\
\hline & Low & $\begin{array}{l}\text { Owners in this quadrant perceive that a } \\
\text { succession will have important costs for } \\
\text { both the family and the business. Thus, } \\
\text { they will be more likely to sell the } \\
\text { business, or to avoid thinking about the } \\
\text { succession process. }\end{array}$ & $\begin{array}{l}\text { Owners in this quadrant perceive the } \\
\text { benefits for the family from engaging in } \\
\text { the succession process, but also see the } \\
\text { costs that this process can bring to the } \\
\text { business. Thus, they will be interested in } \\
\text { engaging in succession only when they } \\
\text { have a family member to be the successor. }\end{array}$ \\
\hline
\end{tabular}

From our point of view, there are additional factors that also paly a role when making decisions about transitions. As mentioned earlier the evaluation of the four contextual aspects in which the business operates is essential when determining the type of succession transition to engage in. Thus, in the following section we combine importance of family and business with the understanding of contextual factors to explain how they influence incumbent decisions about transitions.

\section{Deciding the Type of Succession Transition to Engage in}

Building on the theory of planned behavior, we have argued that an owner's intent to engage in a particular type of succession is the result of their attitudes towards that particular type of succession, subjective norms and perceived behavioral control. This theory suggests that an incumbent will engage in a particular type of succession when they have positive attitudes toward that type of transition, when important others (i.e., with whom they want to comply) also think positively about this transition as being positive, and when incumbents perceive that they have the capabilities and resources to go through with the transition. Thus, we argue that an incumbent's decision of what type of succession to engage in will depend on the attitudes that they hold towards the transition, the subjective norms and incumbent perceptions of how easy or difficult it will be to engage in that transition. Given this we advance the following proposition: 
P4: An incumbents intention to engage in a particular type of transition will be positively related to their attitudes towards that transition, the positive evaluations of important others, and the belief that they have the resources and capabilities to engage in that transition.

There are important factors to consider when using this theoretical framework to understand how people make decisions about behavior. The first consideration is that individuals may place different weight on the importance they give to attitudes, subjective norms, and perceived behavioral control when making decisions. This means that while for some incumbents they attitudes they hold about the transition may be weighted higher than subjective norms of perceived behavioral control, others may value the opinion of others more, or their perceptions about how easy or difficult it might be to engage in a behavior. Meta-analytic research conducted in this area has found that although individuals may differ in the weigh they give to these three components, attitudes has the strongest relationship with behavioral intentions [33]. A second consideration comes from the belief that the three factors that predict behavior intention (i.e., attitudes, subjective norms, and perceived behavioral control) can influence one another. Empirical research up does not support this idea. Thus, in this paper we assume that these three factors are independent of each other. A final consideration refers to the role of emotions in the decision-making process. Although TPB is rational model, attachment and interdependencies of an emotional nature can play a role in the beliefs and evaluation of those beliefs.

In this model we argue that the combination of contextual factors with the concern the incumbent has about family and business influences their attitudes, subjective norms and perceived behavioral control towards type of succession transition. As seen in Table 3, we argue that there are different contextual factors that combined need to be considered in conjunction with the importance of family and business to determine the valence of the three components that will influence the incumbent's choice of a succession strategy. Incumbents will be likely to select intra-family succession under the following condition:

- They have high concern for family.

- A family successor is willing and able to take the business over.

- The family is committed to the business.

- The business has viability in the future.

- The industry also has a positive outlook in the future.

- The incumbent has a long-term orientation focus.

- Tax and state laws provide benefits for keeping the business in the family.

- The family supports and is committed to the business.

And, the incumbent perceives that they have the resources and capabilities to teach the successor about the business. 
Table 3. Identifying decisions about succession transitions.

\begin{tabular}{|c|c|c|c|}
\hline $\begin{array}{c}\text { Incumbent's } \\
\text { Perception/Evaluation }\end{array}$ & Intra-Family Transition & Non-family Transition & No Transition \\
\hline \multicolumn{4}{|c|}{ Family Context } \\
\hline Family dynamics & Non-destructive conflict & $\begin{array}{l}\text { Non-destructive or } \\
\text { destructive conflict }\end{array}$ & $\begin{array}{l}\text { Non-destructive or } \\
\text { destructive conflict }\end{array}$ \\
\hline $\begin{array}{c}\text { Availability and willingness } \\
\text { of successor }\end{array}$ & Yes & $\begin{array}{l}\text { Successor is willing and } \\
\text { not currently available }\end{array}$ & No \\
\hline Family commitment to business & Yes & Yes & No \\
\hline \multicolumn{4}{|c|}{ Business Context } \\
\hline Financial state of business & $\begin{array}{l}\text { Good or with } \\
\text { future potential }\end{array}$ & Good or with future potential & $\begin{array}{l}\text { Good or with future } \\
\text { potential/not positive }\end{array}$ \\
\hline Organizational size & Smaller & Small/large & Small/large \\
\hline Concentration of Ownership & $\begin{array}{l}\text { Concentrated among } \\
\text { some family members }\end{array}$ & $\begin{array}{c}\text { Concentrated or dispersed } \\
\text { among family members }\end{array}$ & $\begin{array}{l}\text { Concentrated/dispersed } \\
\text { among family members }\end{array}$ \\
\hline Viability of the business & Has potential & Has potential & Has potential/no viability \\
\hline Organizational culture & $\begin{array}{l}\text { Positive culture that } \\
\text { shows commitment }\end{array}$ & $\begin{array}{l}\text { Positive culture that } \\
\text { shows commitment }\end{array}$ & $\begin{array}{l}\text { Positive culture that } \\
\text { shows commitment }\end{array}$ \\
\hline \multicolumn{4}{|c|}{ Industry Context } \\
\hline State of industry & Good & Good & Good/decline \\
\hline Future opportunities & Good & Good & Good/no opportunities \\
\hline $\begin{array}{c}\text { Type of knowledge } \\
\text { necessary for success }\end{array}$ & $\begin{array}{c}\text { Industry specific and } \\
\text { family business specific }\end{array}$ & $\begin{array}{c}\text { Industry specific and not } \\
\text { family specific }\end{array}$ & $\begin{array}{c}\text { Industry specific and } \\
\text { not family specific }\end{array}$ \\
\hline \multicolumn{4}{|c|}{ Cultural Context } \\
\hline Social norms & $\begin{array}{l}\text { Long-term orientation and } \\
\text { importance of keeping it in } \\
\text { the family }\end{array}$ & Long-term orientation & Short-term orientation \\
\hline Law & $\begin{array}{c}\text { Considerations estate and } \\
\text { labor laws of country }\end{array}$ & $\begin{array}{c}\text { Considerations estate and } \\
\text { labor laws of country }\end{array}$ & $\begin{array}{c}\text { Considerations estate and } \\
\text { labor laws of country }\end{array}$ \\
\hline Concern for family & High & Low/high & Low/high \\
\hline Concern for business & Low/high & High & Low/high \\
\hline
\end{tabular}

There are two sets of factors that may influence the incumbent's choice to engage in non-family succession transitions. On one side, it may be that the incumbent decides to transition out of the business because although the family is supportive and willing to be involved in the business they might not have a successor ready to take over the business. That is, the successor may be too young, may not have the education, or may be beginning their career in the company. Under these conditions, the incumbent may feel that the best way to keep the business in the family and prepare the successor is by having an outsider manage the business while the successor learns about his/her role. The second set of factors that may lead an incumbent to develop positive attitudes towards a non-family transition are:

- The incumbent may perceive that there is too much destructive conflict in the family that can be enhanced by selecting a family transition in this case showing high concern for the business. 
- The incumbent has high concern for the business and does not perceive that a family member can do justice to the business.

- There may not be a family successor that is willing and able to take over the business.

- The incumbent may perceive that the family is not committed to the business.

- The business and the industry are perceived as having potential and viability in the future.

- The incumbent is long-term oriented.

Finally, the factors that are likely to enhance the incumbent's consideration of the no transition option are the following:

- The incumbent perceives that the family is not committed to the business, that there is no successor that is willing or able to take over the business, and that there is destructive conflict in the family context.

- The incumbent perceives that there are problems with the future viability of the business.

- The industry might be in decline and there are no opportunities for the business in the future.

- The incumbent might be short term oriented.

- Estate and tax laws might prevent the business from transitioning to family or non-family stakeholders.

\section{Discussion}

The purpose of this paper was to conceptually explore the factors that influence a successors decision about what type of succession transition an incumbent chooses and how they play a role in this decision. We view the succession transition as the culmination of a decision-making process. In this process the incumbent evaluates contextual factors (i.e., industry, firm, family, and cultural) to gather information about the strengths and weaknesses a firm and a family have before entering the succession process. The incumbent also evaluates the importance that they place in the family and in the business. Following this the incumbent combines their evaluation of the context with the importance of family and business to determine their attitudes, subjective norms and perceived behavioral control regarding each type of transition. Thus, our model builds on the theory of planned behavior and the SEW framework to understand decision-making choices about succession transitions.

Similar to others $[3,7,8]$, we argue that the succession process is full of decision-making events that we still do not understand very well. Thus, our model provides a conceptual representation of how initial decisions about transitions are likely to occur. We believe that there are at least two reasons for why this paper is important. First, to enhance our understanding of succession we also need to better comprehend the decision-making events that are part of the succession, and how owners make the decisions involved in these events. Understanding both of these ideas can help family business be successful during the succession process. Second, understanding that owners may have the intent to engage in different types of succession may also help better define what is a successful succession process. In this case success may entail that a family business owner achieves the type of succession that they intended initially. Viewing the success of succession process can help us re-evaluate when and why family business successions fail. 


\section{Implications of Our Succession Intent Model}

From our point of view, our model can have several important implications for theory. First, thinking about succession intent as a dependent variable can be useful in understanding why succession occurs and why it is successful. Although previous research has suggested that one of the characteristics of family firms is their intent to engage in succession processes inside of the family, we do not understand when do family business owners have these intentions, how this decision comes about and how it can affect other parts of the succession process. Therefore, studying succession intent as a dependent variable can shed light on how family business owners think about this process. A second theoretical implication of our study comes from understanding decision about transition intent separate from succession timing (i.e., when should the succession occur?) or the successor choice (i.e., who should be the successor of the firm?). By separating these three processes researchers can better understand the intricacies of the succession process and how incumbents might approach each of these events differently. Finally, our approach contributes to recent work that has explored other succession options besides intra-family succession [14]. The continuation of this work is helping clarify the previous belief of what represents a successful transition [9]. In particular, our project suggests that in family firms, non-family transition strategies could also represent a benefit to the family and the business.

Our model also has important implications for practice. First, it can help family business consultants guide family business owners in their evaluation of whether succession should occur, and what type of succession they should engage in. We believe that our model provides interesting factors to consider when making decisions about a firm. A second implication that this model can have is the idea of how a family owner weighs their decision by considering both the impact to the family and the impact to the business. From our understanding of the literature, family business researchers tend to focus on the concerns for family sometimes ignoring the concerns that owners may have for the business or other contextual factors. Finally, this paper also has important implications for understanding other decisions during the succession process. For example, the work of Koropp and colleagues [50] suggests that transactions costs during a succession process can affect how succession occurs. Thus, financial resources can impact the decisions of what type of succession to engage in. At the same time, they also indicate that the succession process can have an impact on the financial structure of the business and the financial opportunities of the family. Given this, we believe that we need to further understand this decision-making process.

\section{Ideas for Future Research}

Research in the last decade has moved to understanding issues such as transgenerational intent, transgenerational control intention and family firm exit strategies. This project complements that line of research by suggesting the factors that can influence the intent to engage in different types of succession and by identifying different types of transitions or exit strategies that family business incumbents can engage in. Given this, it would be useful to begin testing the model presented in this paper with family business owners to ascertain how incumbents evaluate their concerns about the family and about the business in their decision making process. It would be useful to begin testing this 
model by conducting in-depth interviews with owners who are thinking about the succession process or have recently begun this process in their firms. In depth interviews can help better understand the intricacies of the decision making process.

Another way to obtain similar information can be by interviewing family business consultants about their experience when helping during the succession process. Given that consultants are very likely to facilitate the succession process they can also have important insights of how family business owners make decisions about whether to engage in the succession process. Finally, survey research could also be developed to test this model. Researchers can work with family business centers, institutes or associations to obtain a population that can answer questions about how they think about the succession process and whether their company should engage in this process or not.

At the same time, it would be interesting to explore incumbent's transition choices by comparing incumbents based on their country of origin. It may be that comparing respondents from Japan and Denmark, for example, could give insights on how family businesses behave in different cultures.

\section{Conclusions}

This paper presents a model of the factors used in the process of determining succession intent. We argue that family business incumbents evaluate contextual factors and then use this information based on the strength and weaknesses they perceive their family firm has. At the same time, owners weigh their concern for the family and concern for the business and use the information about strengths and weaknesses to determine their intent to engage in the succession process. We believe that owners will be more likely to engage in the succession process when they perceive that the business is viable for the future and there are family members who are willing and able to take over the business.

\section{Acknowledgments}

We thank the reviewers for their valuable feedback for making this paper better.

\section{Author Contributions}

All authors came up with the idea and wrote the paper together. All authors contributed equally to this work.

\section{Conflicts of Interest}

The authors declare no conflict of interest.

\section{References}

1. Ward, J.L. Keeping the Family Business Healthy: How to Plan for Continuity Growth, Profitability and Family Leadership; Palgrave Macmillan: Marietta, GA, USA, 2004.

2. Miller, D.; Steier, L.P.; le Breton-Miller, I. Lost in time: Intergenerational succession, change and failure in family firms. J. Bus. Ventur. 2003, 18, 513-531.

3. Le Breton-Miller, I.; Miller, D.; Steier, L.P. Toward an integrative model of FOB succession. Entrep. Theory Pract. 2004, 28, 305-328. 
4. Long, R.G.; Chrisman, J.C. Management succession in family business. In The Sage Handbook of Family Business; Melin, L., Nordqvist, M., Sharma, P., Eds.; Sage Publications: London, UK, 2014; pp. 371-387.

5. Royer, S.; Simons, R.; Boyd, B.; Rafferty, A. Promoting family: A contingency model of family business succession. Fam. Bus. Rev. 2008, 21, 15-30.

6. Sharma, P.; Chrisman, J.J.; Pablo, A.L.; Chua, J.H. Determinants of initial satisfaction with the succession process in family firms: A conceptual model. Entrep. Theory Pract. 2001, 25, 17-35.

7. De Massis, A.; Chua, J.H.; Chrisman, J.J. Factors preventing intra-family succession. Fam. Bus. Rev. 2008, 21, 183-199.

8. Blumentritt, T.; Mathews, T.; Marchisio, G. Game theory and family business succession. Fam. Bus. Rev. 2013, 26, 51-67.

9. Zellweger, T.; Nason, R.; Nordqvist, M. From longevity of the firm to transgenerational entrepreneurship of families: Introducing family entrepreneurial orientation. Fam. Bus. Rev. 2012, 25, 136-155.

10. Miller, D.; Minichilli, A.; Corbetta, G. Is family leadership always beneficial? Strateg. Manag. J. 2013, 34, 553-571.

11. Gedajlovic, E.; Carney, M.; Chrisman, J.J.; Kellermanns, F.W. The adolescence of family firm research: Taking stock and planning for the future. J. Manag. 2012, 38, 1010-1047.

12. Zellweger, T.M.; Kellermanns, F.W.; Chrisman, J.J.; Chua, J.H. Family control and family firm valuation by family CEOs: The importance of intentions for transgenerational control. Organ. Sci. 2012, 23, 851-868.

13. Chua, J.H.; Chrisman, J.J.; Chang, E.P.C. Are family firms born or made? An exploratory investigation. Fam. Bus. Rev. 2004, 17, 37-54.

14. DeTienne, D.R.; Chirico, F. Exit strategies in family firms: How socioemotional wealth drives the threshold of performance. Entrep. Theory Pract. 2013, 37, 1297-1318.

15. Ajzen, I. From intentions to actions: A theory of planned behavior. In Action-Control: From Cognition to Behavior; Kuhl, J., Beckman, J., Eds.; Springer: Heidelberg, Germany, 1985; pp. 11-39.

16. Gomez-Mejia, L.R.; Haynes, K.T.; Nunez-Nickel, M.; Jacobson, K.J.L.; Moyano-Fuentes, J. Socio-emotional wealth and business risks in family-controlled firms: Evidence from Spanish olive oil mills. Adm. Sci. Q. 2007, 52, 106-137.

17. Chua, J.H.; Chrisman, J.J.; Sharma, P. Defining the family business by behavior. Entrep. Theory Pract. 1999, 23, 19-39.

18. Klein, S.B.; Astrachan, J.H.; Smyrnios, K.X. The F-PEC scale of family influence: Construction, validation, and further implication for theory. Entrep. Theory Pract. 2005, 29, 321-339.

19. International Family Enterprise Research Academy (IFERA). Family businesses dominate. Fam. Bus. Rev. 2003, 16, 235-240.

20. Handler, W. Succession in family firms. Entrep. Theory Pract. 1990, 15, 37-51.

21. Sharma, P.; Chrisman, J.J.; Chua, J.H. Predictors of satisfaction with the succession in family firms. J. Bus. Ventur. 2003, 18, 667-687.

22. Eddleston, K.A.; Kellermanns, F.W.; Floyd, S.W.; Crittenden, V.L.; Crittenden, W.F. Planning for growth: Life stage differences in family firms. Entrep. Theory Pract. 2013, 37, 1177-1202. 
23. Longenecker, J.G.; Schoen, J.E. Management succession in family business. J. Small Bus. Manag. 1978, 16, 1-6.

24. Churchill, N.; Hatten, K. Non-market based transfers of wealth and power: A research framework for family business. Am. J. Small Bus. 1987, 11, 51-64.

25. Gersick, K.; Davis, J.; McCollom Hampton, M.; Lansberg, I. Generation to Generation: Life Cycles of the Family Business; Harvard Business School Press: Boston, MA, USA, 1997.

26. DeTienne, D.R. Entrepreneurial exit as a critical component of the entrepreneurial process: Theoretical development. J. Bus. Ventur. 2010, 25, 203-215.

27. DeTienne, D.R.; Cardon, M. Impact of founder experience on exit intentions. Small Bus. Econ. 2012, 38, 351-374.

28. Chua, J.H.; Chrisman, J.J.; Sharma, P. Succession and nonsuccession concerns of family firms and agency relationship with nonfamily managers. Fam. Bus. Rev. 2003, 16, 89-107.

29. Holt, D.T.; Rutherford, M.W.; Kuratko, D.F. Advancing the field of family business research: Further testing the measurement properties of the F-PEC. Fam. Bus. Rev. 2010, 23, 76-88.

30. Chrisman, J.J.; Chua, J.H.; Pearson, A.W.; Barnett, T. Comparing the agency costs of family and nonfamily firms: Conceptual issues and exploratory evidence. Entrep. Theory Pract. 2010, 28, 335-354.

31. Fishbein, M.; Ajzen, I. Belief, Attitude, Intention, and Behavior: An Introduction to Theory and Research; Addison-Wesley: Reading, MA, USA, 1975.

32. Ajzen, I. The Theory of Planned Behavior. Organizational Behavior and Human Decision Processes. Available online: http://www.nottingham.ac.uk/ ntzcl1/literature/tpb/azjen2.pdf (accessed on 15 September 2014).

33. Hale, J.R.; Householder, B.J.; Greene, K.L. The theory of reasoned action. In The Persuasion Handbook: Developments in Theory and Practice; Dillard, J.P., Pfau, M.W., Eds.; Sage Publications: Thousand Oaks, CA, USA, 2002; pp. 259-286.

34. Park, H.S.; Smith, S.W. Distinctiveness and influence of subjective norms, personal descriptive and injunctive norms, and societal descriptive and injunctive norms on behavioral intent: A case of two behaviors critical to organ donation. Hum. Commun. Res. 2007, 33, 194-218.

35. Eagly, A.H.; Chaiken, S. The Psychology of Attitudes; Harcourt Brace: Fort Worth, TX, USA, 1993.

36. Mussolino, D.; Calabrò, A. Paternalistic leadership in family firms: Types and impacts for intergenerational succession. J. Fam. Bus. Strategy 2014, 5, 197-210.

37. Schröder, E.; Schmitt-Rodermund, E.; Arnaud, N. Career choice intentions of adolescents with a family business background. Fam. Bus. Rev. 2011, 24, 305-321.

38. Zellweger, T.; Sieger, P.; Halter, F. Should I stay or should I go? Career choice intentions for students with family business background. J. Bus. Ventur. 2011, 26, 521-536.

39. Carr, J.C.; Sequeira, J.M. Prior business exposure as intergenerational influence and entrepreneurial intent: A theory of planned behavior approach. J. Bus. Res. 2007, 60, 1090-1098.

40. Koropp, C.; Kellermanns, F.W.; Grichnik, D.; Stanley, L. Financial decision-making in family firms: An adaptation of the theory of planned behavior. Fam. Bus. Rev. 2014, 27, 1-21.

41. Kellermanns, F.W.; Eddelston, K.A.; Barnett, T.; Pearson, A. An exploratory study of family member characteristics and involvement: Effects of entrepreneurial behavior in the family firm. Fam. Bus. Rev. 2008, 21, 1-14. 
42. Uhlaner, L.M.; Berent-Braun, M.M.; Jeurissen, R.J.M.; de Witt, G. Beyond size: Predicting engagement in environmental management practices of Dutch SMEs. J. Bus. Ethics 2012, 109, 411-429.

43. Tagiuri, R.; Davis, J.A. On the goals of successful family companies. Fam. Bus. Rev. 1992, 5, 43-62.

44. Cruz, C.; Firfiray, S.; Gomez-Mejia, L.R. Socioemotional wealth and human resource management in family-controlled firms. In Research in Personnel and Human Resource Management; Joshi, A., Liao, H., Martocchio, J.J., Eds.; Emerald Publishing Group: Bingley, UK, 2011; Volume 30, pp. 159-217.

45. Kellermans, F.W.; Eddleston, K.A.; Zellweger, T.M. Extending the socioemotional wealth perspective: A look at the dark side. Entrep. Theory Pract. 2012, 36, 1175-1182.

46. Berrone, P.; Cruz, C.; Gomez-Mejia, L.R. Socio-emotional wealth in family firms: Theoretical dimensions, assessment approaches, and agenda for future research. Fam. Bus. Rev. 2012, 25, 258-279.

47. Morris, M.H.; Williams, R.O.; Allen, J.A.; Avila, R.A. Correlates of success in family transitions. J. Bus. Ventur. 1997, 12, 385-401.

48. Potts, T.L.; Schoen, J.E.; Engel Loeb, M.; Hulme, F.S. Effective retirement for family business owner managers: Perspectives of financial planners-Part 2. J. Financ. Planning 2001, 14, 86-96.

49. Lansberg, I.; Astrachan, J.H. Influence of family relations on succession planning and training: The importance of mediating factors. Fam. Bus. Rev. 1994, 7, 39-59.

50. Koropp, C.; Grichnik, D.; Gygax, A.F. Succession financing in family firms. Small Bus. Econom. 2013, 41, 315-334.

51. Lubatkin, M.H.; Schulze, W.S.; Ling, Y.; Dino, R.N. The effects of parental altruism on the governance of family managed firms. J. Organ. Behav. 2005, 26, 313-330.

52. Habbershon, T.G.; Pistrui, J. Enterprising families domain: Family-influenced ownership groups in pursuit of transgenerational wealth. Fam. Bus. Rev. 2002, 15, 223-237.

53. Molly, V.; Laveren, E.; Deloof, M. Family business succession and its impact on financial structure and performance. Fam. Bus. Rev. 2010, 23, 131-147.

54. Greens Analyseinstitut. I Familiens eje en Undersøgelse af de Familieejede Virksomheder I; Børsen: Copenhagen, Danmark, 2008.

55. Lee, K.S.; Lim, G.M.; Lim, W.S. Family business succession: Appropriation risk and choice of successor. Acad. Manag. Rev. 2003, 28, 657-666.

56. Goto, T. Longevity of Japanese family firms. In The Handbook of Research on Family Business; Poutziouris, P.Z., Smyrnios, K.X., Klein, S.B., Eds.; Edward Elgar: Cheltenham, UK, 2006; pp. 517-536.

57. Birley, S.; Ng, D.; Godfrey, A. The family and the business. Long Range Planning 1999, 32, 598-608.

58. Birley, S. Owner-Manager attitudes to family and business issues: A 16 country study. Entrep. Theory Pract. 2001, 26, 63-76.

59. Yan, J.; Sorensen, R. The effect of Confucian values on succession in family business. Fam. Bus. Rev. 2006, 19, 235-250. 
60. Cennamo, C.; Berrone, P.; Cruz, C.; Gomez-Mejia, L.R. Socio-emotional wealth and proactive stakeholder engagement: Why family-controlled firms care more about their stakeholders. Entrep. Theory Pract. 2012, 36, 1153-1173.

(C) 2014 by the authors; licensee MDPI, Basel, Switzerland. This article is an open access article distributed under the terms and conditions of the Creative Commons Attribution license (http://creativecommons.org/licenses/by/4.0/). 